\title{
The renoprotective effects of sulodexide
}

This article was published in the following Dove Press journal:

Drug Design, Development and Therapy

22 March 2016

Number of times this article has been viewed

\section{Rik HG Olde Engberink Liffert Vogt}

Department of Internal Medicine, Section of Nephrology, Academic Medical Center, University of Amsterdam, Amsterdam, the Netherlands
Correspondence: Liffert Vogt Department of Internal Medicine, Section of Nephrology, Academic Medical Center, University of Amsterdam, Meibergdreef 9, II 05 AZ Amsterdam, the Netherlands

Email l.vogt@amc.nl

\section{Dear editor}

In their meta-analysis, $\mathrm{Li}$ et $\mathrm{al}^{1}$ reported a renoprotective benefit of sulodexide in patients with diabetic nephropathy. This was the first meta-analysis to evaluate the potential anti-albuminuric effects of sulodexide in such patients. Albuminuria reduction with renin-angiotensin-aldosterone system inhibitors is known to beneficially affect renal outcome and represents, together with blood pressure control, the cornerstone of diabetic nephropathy treatment. ${ }^{2-6}$ As (residual) albuminuria is closely related with renal outcome and the reduction in albuminuria is linearly correlated with renoprotection, we need additional measures to reduce the burden of diabetic nephropathy. ${ }^{7}$ The meta-analysis of $\mathrm{Li}$ et $\mathrm{al}^{1}$ therefore addresses a very relevant topic.

In the light of two large randomized, placebo-controlled, double-blind clinical trials that did not show any effect of sulodexide on albuminuria, the results of this meta-analysis are surprising, especially since the majority (86\%) of patients that were included in this meta-analysis were derived from these trials. ${ }^{89}$ We want to address some crucial points that may underlie these remarkable results.

First, in their continuous outcome analysis, Li et al ${ }^{1}$ excluded the trial of Lewis et $\mathrm{al}^{8}$ for unknown reasons. In our opinion, no valid conclusions can be drawn without taking into account this trial, which represented more than a third of the patients who were included in the meta-analysis. Second, the authors assigned arbitrary weights to the other studies that were included in this analysis. For example, the well-designed, multicenter trial of Packham et al that included 1,248 patients with a mean follow-up of 11 months was assigned a $13 \%$ weight, ${ }^{9}$ while a $21.5 \%$ weight was assigned to a single-center trial that included just 36 patients with a follow-up of 3 weeks. ${ }^{10}$ The authors used a random-effects model and determined weight using the inverse variance method. However, it is unclear how the ratio of mean values and accompanying confidence intervals were calculated. The results of the study by Packham et al that were incorporated in this meta-analysis (log ratio of values $0.99,95 \%$ confidence interval 0.68-1.44) do not seem to correspond with the data that were reported in the original paper ( $\log$ ratio of values $0.97,95 \%$ confidence interval $0.91-1.03) .{ }^{9} \mathrm{We}$ think the authors should address more thoroughly how these treatment effects were calculated and provide data of these calculations for each study. Both the addition of the trial by Lewis et $\mathrm{al}^{8}$ and adequate assignment of weights may have a significant impact on the outcome and conclusions of this analysis.

In a second analysis, the authors assessed the treatment success of sulodexide as a binary outcome. The results of this analysis may raise some concern. First, the authors incorrectly reported that 37 patients participated in the sulodexide group of the study by Dedov et al, ${ }^{10}$ while only 18 patients were included. Second, it is unclear 
how the authors calculated the proportion of patients reaching this binary outcome. For instance, Dedov et al stated that " 17 of the 18 sulodexide-treated patients showed a trend toward a decrease in AER". ${ }^{10}$ This is inconsistent with the proportion of $100 \%$ that reached the binary outcome according to Li et al. ${ }^{1}$ In general, such proportions cannot be extracted from the average albuminuria changes that are often reported in studies. The authors should therefore provide more insight and data of their calculations of this binary outcome. Third, out of three sulodexide doses that were investigated by Gambaro et al, ${ }^{11}$ the authors chose to only include the highest and most effective dose. Lower sulodexide doses were no predefined reason for exclusion. It remains unclear why these groups were not taken into account. Finally, the characteristics of the included studies were represented incorrectly in their baseline table (eg, the average amount of proteinuria was not 24.5 and $38.9 \mathrm{~g} / \mathrm{d}$ in the studies of Dedov et $\mathrm{al}^{10}$ and Gambaro et al, ${ }^{11}$ respectively).

Finally, in their discussion section, the authors came up with different mechanisms that may be responsible for the renoprotective effects of sulodexide that were observed in their meta-analysis. ${ }^{1}$ Besides kidney-specific effects of sulodexide, so far overlooked systemic blood pressure effects of sulodexide have recently been reported. ${ }^{12}$ Considering that blood pressure regulation is the basis for renoprotective therapy, sulodexide-induced blood pressure effects are of influence. Indeed, these blood pressure effects were shown to correlate well with changes in albuminuria. ${ }^{12}$ Improved blood pressure control by sulodexide may therefore contribute to the antialbuminuric characteristics of this agent. Without entering the debate whether sulodexide should be further investigated for a possible renoprotective effect, the authors should revise their analysis and adjust their conclusions accordingly.

\section{Disclosure}

The authors report no conflicts of interest in this communication.

\section{References}

1. Li R, Xing J, Mu X, et al. Sulodexide therapy for the treatment of diabetic nephropathy, a meta-analysis and literature review. Drug Des Devel Ther. 2015;9:6275-6283.

2. Brenner BM, Cooper ME, de Zeeuw D, et al. Effects of losartan on renal and cardiovascular outcomes in patients with type 2 diabetes and nephropathy. N Engl J Med. 2001;345:861-869.

3. Lewis EJ, Hunsicker LG, Clarke WR, et al. Renoprotective effect of the angiotensin-receptor antagonist irbesartan in patients with nephropathy due to type 2 diabetes. $N$ Engl J Med. 2001;345:851-860.

4. Ruggenenti P, Fassi A, Ilieva AP, et al. Preventing microalbuminuria in type 2 diabetes. $N$ Engl J Med. 2004;351:1941-1951.

5. Parving HH, Lehnert H, Brochner-Mortensen J, Gomis R, Andersen S, Arner P. The effect of irbesartan on the development of diabetic nephropathy in patients with type 2 diabetes. $N$ Engl J Med. 2001; 345:870-878.

6. Lewis EJ, Hunsicker LG, Bain RP, Rohde RD. The effect of angiotensinconverting enzyme inhibition on diabetic nephropathy. The Collaborative Study Group. N Engl J Med. 1993;329:1456-1462.

7. de Zeeuw D, Remuzzi G, Parving HH, et al. Proteinuria, a target for renoprotection in patients with type 2 diabetic nephropathy: lessons from RENAAL. Kidney Int. 2004;65:2309-2320.

8. Lewis EJ, Lewis JB, Greene T, et al; Collaborative Study Group. Sulodexide for kidney protection in type 2 diabetes patients with microalbuminuria: a randomized controlled trial. Am J Kidney Dis. 2011;58:729-736

9. Packham DK, Wolfe R, Reutens AT, et al; Collaborative Study Group. Sulodexide fails to demonstrate renoprotection in overt type 2 diabetic nephropathy. J Am Soc Nephrol. 2012;23:123-130.

10. Dedov I, Shestakova M, Vorontzov A, Palazzini E. A randomized, controlled study of sulodexide therapy for the treatment of diabetic nephropathy. Nephrol Dial Transplant. 1997;12(11):2295-2300.

11. Gambaro G, Kinalska I, Oksa A, et al. Oral sulodexide reduces albuminuria in microalbuminuric and macroalbuminuric type 1 and type 2 diabetic patients: the Di.N.A.S. randomized trial. J Am Soc Nephrol. 2002;13(6):1615-1625.

12. Olde Engberink RH, Rorije NM, Lambers Heerspink HJ, De Zeeuw D, van den Born BJ, Vogt L. The blood pressure lowering potential of sulodexide - a systematic review and meta-analysis. Br J Clin Pharmacol. 2015;80(6):1245-1253.

Dove Medical Press encourages responsible, free and frank academic debate. The content of the Drug Design, Development and Therapy 'letters to the editor' section does not necessarily represent the views of Dove Medical Press, its officers, agents, employees, related entities or the Drug Design, Development and Therapy editors. While all reasonable steps have been taken to confirm the content of each letter, Dove Medical Press accepts no liability in respect of the content of any letter, nor is it responsible for the content and accuracy of any letter to the editor.

\section{Publish your work in this journal}

Drug Design, Development and Therapy is an international, peerreviewed open-access journal that spans the spectrum of drug design and development through to clinical applications. Clinical outcomes, patient safety, and programs for the development and effective, safe, and sustained use of medicines are a feature of the journal, which has also been accepted for indexing on PubMed Central. The manuscript management system is completely online and includes a very quick and fair peer-review system, which is all easy to use. Visit http://www.dovepress.com/testimonials.php to read real quotes from published authors. 